\title{
Hypnotherapy to Promote Weight Loss at First Trimester on Pregnant Women with Emesis Gravidarum at Muhammadiyah Gresik Hospital
}

\section{Siti Hamidah $^{1}$, Siti Mudlikah ${ }^{2}$}

${ }^{1}$ Diploma III of Midwifery Academy, Health Faculty, Muhammadiyah Gresik University

${ }^{2}$ Diploma IV of Midwifery

Academy, Health Faculty, Muhammadiyah Gresik University

Email:

sthamidahtw@gmail.com

Received: October 10, 2020

Accepted : November 23, 2020

Published : November 30, 2020

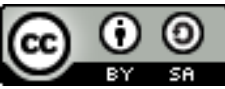

\begin{abstract}
Background: The nutritional status of pregnant mothers affects the growth and development of fetus in the womb. The effort of hypnotherapy with the method of unconscious mind makes the condition relaxed, calm, focus decreases stress and affects the weight of early pregnant women.

Purpose: The purpose of the study was to identify hypnotherapy interventions in young expectant mothers (first trimester) with emetic gravidarum on maternal weight gain.

Methods: This research is a type of experimental quasi, with time series design in September 2019-April 2020. The research population is all of the first tirmester pregnant mothers at Muhammadiyah Gresik Hospital. Number of samples selected 100 respondents with quota sampling. Data collection with KIA books on first, second and third visit. Data analysis with normality test and ANOVA test.

Results: The results showed a result of $\mathrm{p}<0.001$, meaning that $\mathrm{H} 0$ was rejected, i.e. there is an average difference in weight increase in the three groups of measurement time intervals $(p<0.05)$. The caller's conclusion is a hypnotherapy influence with the weight gain of pregnant women.

Conclusion: Hypnotherapy can affect mothers on a psychic basis about the importance of eating while pregnant for the health of mothers and babies that are conceived.
\end{abstract}

Keywords: Hypnotherapy, pregnant women, emetic gravidarum, women's weight

Copyright @ 2020 IIK STRADA Indonesia All right reserved.

This is an open-acces article distributed under the terms of the Creative Commons Attribution-ShareAlike 4.0 International License.

\section{BACKGROUND}

The nutritional status of pregnant mothers affects the growth and development of the fetus in the womb (Witari \& Dewianti, 2020). Less or worse nutritional Status results in chronic energy deficiency at risk and risks of stunting born babies (RI, 2018). Nutritional needs during pregnancy experienced an increase of 15\%, if not fulfilled then the risk of a defective fetus or born low birth weight (BBLR), anemia baby, even neonatal death (Ministry of Health Republic of Indonesia, 2014).

Symptoms of chronic energy deficiency (KEK) will feel weak body, pale face (Sari \& Harjanti, 2016). In addition, mother with KEK can be at risk of anemia, easy infection, and mother's weight does not increase. The weight of pregnant women does not rise to influence the quality of growth and development of the fetus in its womb (Nurastuti \& Triasih, 2014). The average weight 
gain for mothers during pregnancy is $10-15 \mathrm{~kg}$ which is one trimester increase by $1 \mathrm{~kg}, 2$ and 3 trimester of about $0.3-0.7 / \mathrm{kg} / \mathrm{week}$. The weight gain during pregnancy is $10-12 \mathrm{~kg}$. At the beginning of the first trimester pregnancy gain weight $0.5-1 \mathrm{~kg}$, while the second trimester of $3 \mathrm{~kg}$ and three trimesters $6 \mathrm{~kg}$ (Hughes \& Pierson, 2014).

Emesis gravidarum or better known as morning sickness is a symptom of nausea usually accompanied by vomiting which in general occurs in early pregnancy, this condition is generally experienced by more than half of pregnant women caused due to increased levels of Estrogen, Chorionic Gonadotropin hormone (HCG), increased sensitivity to the smell, and the psychology factor of pregnant women. Usually after three months this complaint will diminish and disappear by itself (Manuaba, 2015).

Results of the study that the shortage of pregnant women's food is due to the parity factor (Ervinawati, Wirda, \& Nurlisis, 2019). The increase in weight of pregnant mothers has a big impact $88 \%$ on the body weight and length of the born baby. In research there is no relationship of weight gain of pregnant mothers with the weight of birth baby (Wahyuni, et al., 2016). The single Trimester of pregnancy increased the progesterone and esterogen hormones affecting appetite (Burmanajaya \& Agustina, 2020). About 60-80\%, not appetite and weight does not rise even decreases (Prawihardjo, 2010).

The influence of hypnotherapy causes weight loss does not rise or equal. Hypnotherapy in relaxed condition, calm and focus reduces stress, panic, reduce the weight of pregnant women decline (Beevi, Low, \& Hassan, 2016). Preliminary study dated 15 October 2019 in Muhammadiyah Gresik Hospital from 30 one trimester pregnant mothers as much as 10 mothers (33\%) Experiencing weight loss. Maternal weight monitoring begins with a 6 -week pregnancy up to 14 weeks of pregnancy. From the explanation above, the authors are interested to do research on hypnotherapy to increase the weight of one trimester pregnant mother in Muhammadiyah Hospital.

\section{OBJECTIVE}

The purpose of the study was to identify hypnotherapy interventions in young expectant mothers (TM I) with emetic gravidarum on maternal weight gain. The novelty of researchers is to intervene hypnotherapy in pregnant women with an emetic gravidarum associated with weight gain by using experimental quasi research design rarely found in previous research. The benefits of research is able to provide therapy to pregnant women with emetic gravidarum to cope with weight loss through hypnotherapy, so that pregnant women are in good health condition for mother and baby.

\section{METHODS}

\section{Research participants}

This research is a type of quasi experiment, with the design of time series in September 2019-April 2020. The research population is all of the TM I pregnant mothers at Muhammadiyah Gresik Hospital. Number of samples selected 100 respondents with quota sampling. Criteria of sampling inclusion of pregnant women who check in the hospital Muhammadiyah Gresik with the complaint of Emetic Gravidarum, the number of children $\leq 4$ people and do not have an accompanying disease.

\section{Research procedure}

Variable research consists of independent variables namely hypnotherapy interventions and dependent variables ie the weight of pregnant women. After obtaining a sample of research, the pregnant woman will be given a hypnotherapy intervention, then seen her weight on her first visit, second visit and third-trimester visit in the 1 st trimesters (6 weeks of pregnancy up to 14 weeks).

\section{Instruments}

Data collection with KIA book on first, second and third visit in 1st trimester.

\section{Data analysis}

Analysis of research results began from univariate analysis and bivariate analysis. Univariate analysis is used to description the characteristics of continuous data samples and categorical data. Bivariate analysis is an experimental test to determine the influence of intervention carried out with the first phase, namely normality and homogeneity. If normal and homogeneous data distribution then test 
repeated measure ANOVA, but if the data distribution is not normal and not homogeneous then use alternative test, namely Friedman Test. Data analysis using IBM SPSS 23 software.

\section{RESULTS}

\section{Univariat Analysis}

In this analysis will describe the distribution of each of the general data variables of the study.

Table 1 Variable Frequency Distribution Common Data Research

\begin{tabular}{lccc}
\hline Variable & Category & Frequensi & Percentage \\
\hline Mother Aged & $<20$ age & 2 & $2.0 \%$ \\
& $20-35$ age & 90 & $90.0 \%$ \\
Mother Education & $>35$ age & 8 & $8.0 \%$ \\
& SD & 8 & $8.0 \%$ \\
& SMP & 12 & $12.0 \%$ \\
\multirow{4}{*}{ Mother Work } & SMA / SMK & 65 & $65.0 \%$ \\
& D3 / S1 & 15 & $15.0 \%$ \\
& Housewives & 48 & $48.0 \%$ \\
Parity & Swasta & 37 & $37.0 \%$ \\
& Self employed & 11 & $11.0 \%$ \\
& Teacher & 4 & $4.0 \%$ \\
& Primipara & 54 & $54.0 \%$ \\
& Multipara & 46 & $46.0 \%$ \\
\hline
\end{tabular}

Table 1 shows the frequency distribution of the common variable data. In the variable age mother is mostly age of mothers in the category of 20-35 years, namely 90 respondents $(90.0 \%)$. Meanwhile, at least the mother is in the age category of less than 20 years, which is 2 respondents $(2.0 \%)$. In the mother of education, most of the mothers are in high school or vocational category, which is 65 respondents $(65.0 \%)$. Meanwhile, at least the mother is in elementary education category, which is 8 respondents $(8.0 \%)$. In the variable mother's job most mothers work as IRT, which is 48 respondents $(48.0 \%)$. Meanwhile, at least the mother works as a teacher, which is 4 respondents $(4.0 \%)$. In the parity variable most mothers in the category Primipara, which is 54 respondents (54.0\%). Meanwhile, the fewest mothers are in the Multipara category, which is 46 respondents (46.0\%).

\section{Bivariat Analysis}

In bivariate analysis, this will explain the influence of hypnotherapy on the increase in the body weight of pregnant women with emetic gravidarum.

Table 2 Test the normality variable weight enhancement of mothers on First visit, second visit and third visit

\begin{tabular}{|c|c|c|c|}
\hline & Statistic & df & Sig. \\
\hline Standardized Residual for & 0.100 & 100 & 0.015 \\
\hline Weight loss on first visit at TM 1 & & & \\
\hline $\begin{array}{l}\text { Standardized Residual for } \\
\text { Weight on second visit at TM } 1\end{array}$ & 0.117 & 100 & 0.002 \\
\hline $\begin{array}{l}\text { Standardized Residual for } \\
\text { Weight loss on third visit on TM } 1\end{array}$ & 0.107 & 100 & 0.007 \\
\hline
\end{tabular}

Table 2 shows the results of the normality test standardized residual variables in 100 respondents in the study result of the value $\mathrm{p}$ on the residual standardized for weight loss on the first visit in the 1st trimester, i.e. $0.015(\mathrm{P}<0.05)$, standardized residual for weight loss on the second visit in the 1st trimester, $0.002(\mathrm{P}<0.05)$, and standardized residual for weight loss on the third visit in the 1st trimester, i.e. $0.007(\mathrm{P}<0.05)$. This shows the third residual standardized shows the results of 
abnormal data distribution, so that the experimental test used is an alternative test of repeated measure ANOVA, namely Friedman Test.

Table 3. Output mean ranks show average weight in rank form. The most noticeable weight is shown in the weight of the third visit in the 1st trimester after hypnotherapy, which is a $2.99 \mathrm{~kg}$ increase, while the lowest weight is shown in the body weight on the first visit in the 1st trimester after hypnotherapy, which is increased by $1.01 \mathrm{~kg}$.

Table 3 The Friedman Test Influences Hypnotherapy Against Improvement Weight Loss Young Pregnant Mother With Emesis Gravidarum

\begin{tabular}{lccccc}
\hline & Mean Rank & Min & Max & N & Sig. \\
\hline Weight loss on first visit at TM 1 & 1.01 & 34.0 & 78.9 & 100 & $<0.001$ \\
Weight loss on second visit at TM & 2.01 & 34.6 & 79.0 & & \\
1 & & & & & \\
Weight loss on thirdt visit at TM & 2.99 & 34.0 & 80.1 & & \\
1 & & & & & \\
\hline
\end{tabular}

The "Min" value shows the lowest weight number and the "Max" value indicates the highest weight number in the respondent in each visit in the 1st trimester. On the first visit in the 1st trimester of the lowest weight is $34.0 \mathrm{~kg}$, while the highest weight is $78.9 \mathrm{~kg}$. On the second visit in the 1st trimester of the lowest weight is $34.6 \mathrm{~kg}$, while the highest weight is $79.0 \mathrm{~kg}$. On the third visit in the 1st trimester of the lowest weight is $34.0 \mathrm{~kg}$, while the highest weight is $80.1 \mathrm{~kg}$.

The Test output Table Statistic Friedman test shows the result of the P-number $<0.001$, which means that $\mathrm{HO}$ is rejected, i.e. there is an average difference in weight gain in the third group of measurement time intervals $(\mathrm{P}<0.05)$. It can thus be concluded that hypnotherapy can actually increase the body weight of the 1st trimester pregnant with emetic gravidarum during pregnancy.

\section{DISCUSSION}

Emesis Gravidarum experienced pregnant mothers who have vomiting nausea and sometimes interfere with maternal activity, affecting the health of the fetus and mother. Usually vomiting nausea often occurs in the morning, can even arise at any time or sometimes occur at night (Christiani \& Andayani, 2019). Most of the pregnant women $70-80 \%$ experience morning sickness and as many as $1-2 \%$ of all pregnant mothers experience extreme morning sickness (Dean, 2016). Pregnant women will experience various problems such as dehydration, fluid and electrolyte balance disorders, fatigue and acid-base disorders and stomach that can cause pain and even bleeding that can harm the mother and fetus (Campbell, et al., 2016).

Research conducted by Fuchs in 201 first trimester pregnant women using pharmacological therapy only 63 patients (20.4\%) Recovered, the remaining 138 patients (79.6\%) Failed. Furthermore, a total of 138 patients who failed pharmacological therapy performed hypnotherapy and the results as much as $70 \%$ were very good, $19 \%$ good, $11 \%$ bad (Fuchs, 2016). The difference in weight immediately after hypnotherapy allows increased motivation and confidence in patients to successfully reduce the complaints of nausea and vomit during pregnancy, so that the weight of pregnant women did not experience a drastic decline. It is related to the theory of man body dualism, what we think will affect the physical state. Our thoughts and feelings are also influenced by what we feel physically (judge, 2018).

Hypnotherapy is one way that is very easy, fast, effective and efficient in reaching out the unconscious mind, doing reeducation and healing the Sick Mind (Agah, 2015). Treatment of nausea and vomiting can also be done through hypnotherapy (Sahour et al., 2019). It is reinforced by the opinions of Madrid that vomiting nausea in pregnancy is often caused by unresolved emotional or psychological problems that can be quickly solved with hypnosis (Madrid, Giovanolli, \& Wolf, 2016).

Hypnotherapy encourages each individual to be directed into exploring ways of thinking that support to maintain weight and direct behaviors to elevate it to expectant mothers (McCormack, 2010). Nonpharmacological treatment of normal complaints experienced in pregnant women becomes an option to treat disorders (Matthews et al., 2015). This is because in pregnant women with the condition of emetic gravidarum have difficulty when administered by parenteral drugs (Karaman et al., 
2018) treatment is done naturally in pregnancy is believed to be safer and lower risk compared to consuming the drug used (Bayles, 2007).

Maternal weight gain during pregnancy affects the nutritional status of mothers and their parents. If the nutritional status of mothers before pregnancy in good condition, mother will give birth to a healthy baby, enough months and normal body weight (Legrand et al., 2017). Poor nutritional Status before and during pregnancy will cause low birth weight babies (BBLR), the development of fetal brain, anemia in newborns, infected newborns, and abortion (Meireles, Calara, Pedro, \& Maria, 2014).

\section{CONCLUSION}

The conclusion of the study was the influence of hypnotherapy with the weight gain of pregnant women in the 1st trimester. Hypnotherapy can affect mothers on a psychic basis about the importance of eating while pregnant for the health of mothers and babies that are conceived. Hypnotherapy is also regarded as an effective approach in every behaviour and reduction of complaints occurring during pregnancy, due to pain control such as muscle relaxation, perception changes and reduction of cognitive disorders, so that expectant mothers are in a relaxed condition.

The advice of researchers for further researchers is to increase the addition of interventions in order to compare the influence of various kinds of interventions to the health of pregnant women, especially in the point of weight increase of pregnant women TM 1. In addition, the advice given to the respondent is that the expectant mothers can apply hypnotherapy to oneself to make the body relaxed and comfortable, thereby reducing the complaints that arise during the pregnancy.

\section{ACKNOWLEDGMENTS}

The author thanked the pregnant woman at the Muhammadiyah Hospital of Gresik, who was willing to become a research respondent. Thank you also researchers speak to the University of Muhammadiyah Gresik which provides a research container to be able to conduct studies that can be beneficial to readers and add to the science reference in the field of health education especially pregnancy.

\section{CONFLICTS OF INTEREST}

None.

\section{REFERENCES}

Agah, M. (2015). New approaches of hypnotherapy in pain treatment and its strategic necessities in Iran. Journal of Strategy, 19(55), 261-278.

Bayles, B. P. (2007). Herbal and Other Complementary Medicine Use by Texas Midwives. Journal of Midwifery and Women's Health, 52(5), 473-478. https://doi.org/10.1016/j.jmwh.2007.03.023.

Beevi, Z., Low, W. Y., \& Hassan, J. (2016). Impact of hypnosis intervention in alleviating psychological and physical symptoms during pregnancy. American Journal of Clinical Hypnosis, 58(4), 368-382. https://doi.org/10.1080/00029157.2015.1063476.

Burmanajaya, B., \& Agustina, A. (2020). Hipnoterapi dapat Mengurangi Derajat Emesis pada Ibu Hamil Trimester Pertama. Jurnal Ilmu Keperawatan Jiwa, 3(1), 33. https://doi.org/10.32584/jikj.v3i1.477.

Campbell, K., Rowe, H., Azzam, H., \& Lane, C. A. (2016). The Management of Nausea and Vomiting of Pregnancy. Journal of Obstetrics and Gynaecology Canada, 38(12), 1127-1137. https://doi.org/10.1016/j.jogc.2016.08.009.

Christiani, N., \& Andayani, A. (2019). Perbedaan Kadar Hormion Chorionic Gonadotrophine (Hcg) Pada Ibu Hamil Trimester I Yang Mengalami Hiperemesis Gravidarum Sebelum Dan Setelah Dilakukan Hipnotherapi Di Rumah Sakit Umum Ungaran Kabupaten Semarang. Indonesian Journal of Midwifery (IJM), 2(2). https://doi.org/10.35473/ijm.v2i2.286.

Dean, E. (2016). Morning sickness. Nursing Standard (Royal College of Nursing (Great Britain): 1987), 30(50), 15. https://doi.org/10.7748/ns.30.50.15.s16.

Ervinawati, E., Wirda, A., \& Nurlisis, N. (2019). Determinant of Chronic Energy Malnutrition (CEM) in Pregnant Woman at Lubuk Muda Public Health Center. Jurnal Kesehatan Komunitas, 4(3), 120-125. https://doi.org/10.25311/keskom.vol4.iss3.289.

Fuchs, K. (2016). Treatment of hyperemesis gravidarum by hypnosis. In Psychological Influences and Illness: Hypnosis and Medicine (pp. 43-56). https://doi.org/10.1007/978-1-349-06686-5. 
Hughes, E., \& Pierson, R. (2014). Pregnant Woman. Journal of Obstetrics and Gynaecology Canada, 36(4), 368. https://doi.org/10.1016/S1701-2163(15)30614-9.

Karaman, E., Kaplan, Ş., Alpaycı, M., Çetin, O., Kolusarı, A., \& Şahin, H. G. (2018). Can kinesio taping be a novel treatment option for emesis gravidarum? A randomized preliminary study. Eastern Journal of Medicine, 23(3), 199-205. https://doi.org/10.5505/ejm.2018.54254.

Legrand, F., Grévin-Laroche, C., Josse, E., Polidori, G., Quinart, H., \& Taïar, R. (2017). Effects of hypnosis during pregnancy: A psychophysiological study on maternal stress. Medical Hypotheses, 102, 123-127. https://doi.org/10.1016/j.mehy.2017.03.026

Madrid, A., Giovanolli, R., \& Wolf, M. (2016). Treating Persisten Naucea of Pregnancy With Hypnosis: Our Cases. American Journal of Clinical Hypnosis, 54(2), 107-115. Retrieved from http://www.tanfondline.com/doi\%0A/abs/10.1080/00029157.2011.605480

Manuaba. (2015). Ilmu Kebidanan Penyakit Kandungan dan KB. Jakarta: EGC.

Matthews, A., Haas, D. M., O’Mathúna, D. P., \& Dowswell, T. (2015). Interventions for nausea and vomiting in early pregnancy. Cochrane Database of Systematic Reviews, Vol. 2015. https://doi.org/10.1002/14651858.CD007575.pub4

McCormack, D. (2010). Hypnosis for hyperemesis gravidarum. Journal of Obstetrics and Gynaecology, 30(7), 647-653. https://doi.org/10.3109/01443615.2010.509825

Meireles, J., Calara, M., Pedro, H., \& Maria, E. (2014). Body Dissatisfaction Among Pregnant WOmen: an Integrative Review of The Literature. Ciencia an Satide Coletiva, 20(7).

Nurastuti, Y., \& Triasih, D. (2014). Hubungan Kenaikan Berat Badan Ibu Hamil Dan Usia Kehamilan Dengan Berat Badan Bayi Lahir. Obstretika, 3(1), 1-15.

Rashid, M., Rashid, M. H., Malik, F., \& Herath, R. P. (2012). Hyperemesis gravidarum and fetal gender: A retrospective study. Journal of Obstetrics and Gynaecology, 32(5), 475-478. https://doi.org/10.3109/01443615.2012.666580

RI, K. (2018). Data dan Informasi Profil Kesehatan Indonesia.

Sahour, A., Fakhri, M. K., Pourasghar, M., Sahour, A., Fakhri, M. K., \& Pourasghar, M. (2019). Investigating the Effect of Hypnotherapy on Reducing Anxiety and Pain during Labor. BrainBroad Research in Artificial Intelligence and Neuroscience, 10(3), 25-33.

Sari, S. D., \& Harjanti, A. I. (2016). PENGELOLAAN KEHAMILAN 18 MINGGU DENGAN KEK (KEKURANGAN ENERGI KRONIS). Jurnal Ilmu Keperawatan Dan Kebidanan. Retrieved from http://182.253.197.100/e-journal/index.php/jikk/article/view/592

Wahyuni, Purwanto, A. D., \& Umbul, C. (2016). Hubungan Antara Umur Kehamilan,Kehamilan Ganda,Hipertensi dan Anemia Dengan Kejadian Bayi Berat Lahir Rendah (BBLR). Jurnal Berkala Epidemiologi, 4(3), 384-395. https://doi.org/10.20473/jbe.v4i3

Witari, N. N. D., \& Dewianti, N. M. (2020). Effectiveness of Providing Self-Management Education to Deal with Emesis Gravidarum on Decreasing Nausea Vomiting Pregnancy (NVP) at Private Practice Midwives Puskesmas IV Denpasar Selatan Work Area. Indian Journal of Public Health Research \& Development, 11(1), 1387. https://doi.org/10.37506/v11/i1/2020/ijphrd/194038 